\title{
POLITISASI AGAMA VERSUS SEKULARISASI POLITIK Perdebatan Perjumpaan Agama dengan Negara
}

\author{
Mukhtar
}

\author{
(IAI DDI Polewali Mandar)
}

\begin{abstract}
Abstrak
Studi ini menggambarkan perdebatan para pemikir Islam pada umumnya maupun cendekiawan Muslim di Indonesia pada khususnya tentang hubungan antara agama dan negara dengan permaslahan tentang bagaimana prinsip-prinsip Islam tentang agama dan negara, bagaimana sikap para pemikir Islam tentang wacana hubungan agama dan negara.

Kajian ini bersifat deskriftif analisis-kritis dengan menggunakan pendekatan sosiopolitik dan agama. Di samping juga digunakan pola pikir dialektik dalam mengulas setiap model pemikiran baik yang pro maupun yang kontra.

Hasil temuan dalam kajian tentang hubungan antara agama dan negara didapatkan varian pemikira, hal ini dapat dibagi dalam dua kelompok. Kelompok yang pertama adalah pemikiran yang mendukung bahwa dalam Islam itu mencakup semua permaslahan kehidupan termasuk politik. Untuk pemikiran ini menegaskan adanya sistem politik yang diatur oleh Islam. Refresentasi dari pemikiran ini adalah Abu a'la al-Maududi yang kemudian mendapatkan tantangan keras dari Ibnu Taimiyyah. Kelompok yang kedua adalah pemikiran yang melihat Islam sebagai agama yang tidak sepenuhnya dimasukkan dalam gelanggang politik atau upaya sekularisaasi. Untuk konteks keindonesian, dapat diamati dari pemikiran Nucholish Madjid yang mendengungkan ide-ide pembaharuan, termasuk ide-ide sekularisasi politik dan paham liberal. Ide-ide ini kemudian mendapatkan tanggapan keras dari generasi yang semasa dengan Nurcholish antara lain, Endang Saifuddin, sementara generasi tua termasuk Prof. Rsyidi.
\end{abstract}

\section{Kata Kunci :}

\section{A. Pendahuluan}

Dalam konteks sosiologis, ada pandangan ekstrim mengenai agama yang kaitannya dengan persolan hidup manusia. Pandangan ini mencoba menjelaskan mengapa agama dan negara tidak bisa dipertemukan bahkan berlawanan. Tokoh yang paling mudah dirujuk adalah Karl Marx, dan sampai pada batas tertentu pendapatrnya disokong oleh Weber. Marx sendiri sesungguhnya tidak banyak berbicara tentang agama kecuali sedikit saja. Akan tetapi, meskipun sedikit, kritiknya terasa amat tajam dan bagi penguasa gereja waktu itu amat menyakitkan.

Bagi Marx, ekspresi kehidupan beragama pauayarakatda dasarnya merupakan ekspresi penderitaan sosial. Agama adalah keluh kesah warga masyarakat yang tertindas, agama adalah sentimen suatu dunia yang tak berperikemanusiaan. "agama adalah candu masyarakat", yang hanya memberikan 
penenang sementara, semu, tetapi tidak mampu membongkar dan menghilangkan kondisi-kondisi yang menimbulkan penderitaan. $^{1}$

Pandangan negatif terhadap agama dan perangkat kelembagaannya juga datang, antara lain, filosof semacam Sartre dan Nietzche. Sebagaimana juga Marx, Nietzche dan Sartre menilai agama dan penguasa gereja sebagai kekuatan konservatif yang membelengggu penalaran dan kemerdekaan manusia untuk membangun dunia otonom, tanpa dikekang oleh "tangan Tuhan" yang hadir melalui kekuasaan lembaga dan penguasa agama. ${ }^{2}$

Meski pandangan Marx yang sangat sinis terhadap agama tidak berangkat dari postulat teologi, tapi berangkat dari realitas sosial yang dilihatnya timpang. Kritikannya terhadap agama dilatari terjadinya ketimpangan sosial antara kaum kapitalis dan kaum proletar dimana kaum kapitalis menjadikan agama sebagai alat untuk menindas kaum lemah pada saat itu. Dalam konteks politik Sebenarnya Marx ingin mengingatkan kita terkhusus kepada perilaku politisi yang cenderung menjual "dagangan politiknya" atas nama agama, bahwa jangan agama dijadikan alat politik untuk mengusai orang lain. Masyarakat yang panatisme terhadap agamanya, bisa saja terhipnotis oleh para politisi yang "turun gunung" dengan taktik menggunakan bahasa agama dalam memancing simpati rakyat sehingga muncullah politisassi agama.

${ }^{1}$ Komaruddin Hidayat, Tragedi Raja Midas: Moralitas Agama dan Krisis Modernisme (Jakarta: Paramadina, 1998), h. 10.

${ }^{2}$ Ibid.
Adalah William Montgomery-tokoh orientalis terkemuka yang konsentrasinya meneliti dunia Islam juga berkomentar bahwa hampir setiap Muslim meyakini akan pentingnya prinsip-prinsip Islam dalam kehidupan politik. ${ }^{3}$ Pandangan ini memang tidak bisa dinapikan dengan adanya pemikir bahkan kelompok organisasi tertentu yang memiliki pandangan bahwa agama (Islam) telah mengatur semua tatanan kehidupan termasuk kehidupan politik. Pada sisi lain ditemukan juga pandangan-pandangan yang memisahkan antara urusan agama dengan urusan dunia termasuk urusan politik. Urusan kegaiban tidak bisa dicampur dengan urusan duniawi. Agama adalah menurut pandangan ini adalah hal yang mengurusi persoalan kegaiban sementara politik adalah urusan duniawi yang tidak membutuhkan campur "tangan Tuhan", melainkan campur tangan manusia sendiri. Pandangan inilah yang melahirkan gagasan "sekularisasi politik".

Landasan sekularisasi politik dapat ditelulususri dari gagasan Machiavelli yang menurutnya "memungkinkan untuk dipakai bagi realitas yang ada", tanpa mengenalkan standar nilai-nilai agama. Politik adalah suatu metodologi tertentu yang dicoba dengan berbagai cara sesuai yang diinginkannya setelah menggunakan beberapa alternatif, tanpa menyinggung pentingnya agama yang menghubungkan politik agama dengan tujuan akhirat. $^{4}$ Landasan pemikiran ini dapat dipahami

${ }^{3} I$ Ibid., h. 13.

${ }^{4}$ Rahman Thohir Anshari, Islam dalam Wacana Pemikiran Moderat: Analisis Terhadap Pemikiran Muhammad Quthb dalam Islam Garda Depan: Mosaik Pemikiran Islam Timur Tengah (Bandung: Mizan, 2001), h. 101. 
bahwa tujuan politik itu hanyalah bertujuan kepentingan dunia yang tidak ada kaitannya dengan akhirat.

Padahal menurut Muhammad Imarah, bahwa politik dalam Islam adalah suatu reklamasi etika yang ditunjukkan dengan jalan lurus secara cepat maupun lambat, dan berbuat yang bisa mendekatkan manusia terhadap kebaikan dan keadilan, selalu konsekwen terhadap ajaran Islam. ${ }^{5}$ Pandangan ini menegaskan bahwa manusia dalam dimensi politik Islam mempunyai fungsi sebagai khalifah (mandataris Tuhan) di bumi, yang mempunyai tugas memakmurkan, mengembangkan, dan menjaga keberlangsungan kehidupan manusia. Pandangan yang lebih pulgar dapat ditelusuri dari pemikiran yang menjadikan agama sebagai alat politik dengan alasan agama mencakup semua aspek kehidupan termasuk politik. Pandangan inilah yang melahirkan "politisasi agama".

Pandangan-pandangan yang kontras tentang kaitan agama dan negara merupakan diskursus pemikiran Islam yang terus mengemuka. Dalam wacana pemikiran Islam di Indonesia, juga pernah terjadi perdebatan hangat ketika ide-ide progresif muncul dari kalangan pembaharu Islam yang kemudian mendapat tantangan keras dari kelompok yang curiga dengan kelompok pembaharu tersebut. Dalam konteks ini, akan dikaji bagaimana prinsip-prinsip politik dalam Islam, dan bagaimana perdebatan antara dua pemikiran yang kontras mengenai hubungan agama dan negara.

\section{B. Pengertian politisasi agama dan sekularasi politik}

\section{${ }^{5}$ Ibid.}

Politisasi agama terdiri dari dua kata yaitu politisasi dan agama. istilah politisasi sendiri terdiri dari kata politik. Dalam bahasa inggris politik berasal dari kata politic yang menunjukkan sifat pribadi atau perbuatan. ${ }^{6}$ Dalam bahasa latin disebut politicus dan dalam bahasa Yunani politicos yang berarti relating toa citizen. kedua kata tersebut juga berasal dari kata polis yang bermakna city " kota".

Politic kemudian diserap ke dalam bahasa Indonesia dengan tiga arti. Menurut kamus Umum besar besar bahasa Indonesia politik adalah: segala urusan dan tindakan (kebijaksanaan, sisasat, dan sebagainya) mengenai pemerintahan suatu negara atau terhadap negara lain, tipu muslihat atau kelicikan, dan juga dipergunakan sebagai nama bagi sebuah disiplin pengetahuan, yaitu ilmu politik. ${ }^{7}$ Dalam bahasa Arab politik biasa disebut siyasah atau khiththah yang bermakna siasat, politik dan kebijaksanaan. ${ }^{8}$ Kata poliitik ini ditambah dengan imbuhan sasi yang bermakna upaya atau sebuah gerakan dalam menyebarkan idiologi yang berdasarkan nilai -nilai agama atau norma-norma agama.

Adapun pengertian agama adalah yang menurut Kamus Bahasa Indonesia, agama adalah sistem, prinsip kepercayaan kepada Tuhan, Dewa dan sebagainya dengan ajaran kebaktian dan kewajiban-kewajiban

6 John M.Echols dan Hasan Sadily, kamus Inggris Indonesia (Jakarta: Gramedia, 1981), h. 437.

${ }^{7}$ W.J.S Purdawarminta, Kamus Umum Bahasa Indonesia (Jakarta: Balai Pustaka,1983), h. 763 .

\footnotetext{
${ }^{8}$ Ahmad Warson al-Munawwir, Kamus Al-Munawwir Arab-Indonesia Terlengkap (Yogyakarta: Pondok Pesantren al-Munawwir, 1984), h. 734.
} 
yang telah bertalian dengan kepercayaan itu. ${ }^{9}$

Sementara pengertian sekularisasi yang berasal dari kata latin saeculum, yang berarti zaman sekarang ini. Kata saeculum itu sendiri sebenarnya merupakan salah satu dari dua kata latin yang berarti " dunia" (world), yakni mundus. Hubungan dua kata itu merupakan suatu persoalan yang kompleks. Saeculum itu sendiri merupakan kata waktu, yang sering digunakan untuk menerjemahkan kata Yunani aecon, yang juga berarti zaman. Sementara mundus adalah kata ruang, yang banyak digaunakan untuk menerjemahkan kata Yunani. Cosmos, artinya alam raya, tetapi ada juga yang mengartikan pengertian saeculum dalam makna ganda sekaligus, yakni ruang dan waktu. Dalam konteks ini ruang dihubungkan dengan pengertian duniawi, sedangkan waktu menunjuk pada pengertian sekarang atau zaman kini. dengan demikan kata saeculum bisa diartikan masa kini atau zaman kini, yang berhubungan dengan peristiwa-peristiwa di dunia ini atau peristiwa masa kini. ${ }^{10}$

Dari pengertian kebahasaan tersebut yang dikaitkan dengan kata dunia (world dan cosmos) tersebut atau yang berarti kekinian, maka sekuler itu memang berada pada wilayah keduniawian yang mesti diolah dengan cara pandang dunia. Maka pengertian sekularisasi di atas dapat dipahami istilah sekularisasi politik adalah

\footnotetext{
9 Team Pustaka Phoenix, Kamus Besar Bahasa Indonesia edisi Baru ( jakarta: Kepustakaan Nasional, 2007), h. 14.

10 M. Syafi'i Anwar, Pemikiran dan Aksi Islam Indonesia: Sebuah Kajian Politik Tentang Cendikiawan Muslim Orde Baru ( Jakarta: Paramadina, 19195), h. 67.
}

politik adalah bersifat duniawi yang tidak bisa dicampuri urusan akhirat. Atau dengan bahasa lain harus ada pemisahan antara wilayah politik dan agama.

\section{Teori-teori Hubungan Agama dan Negara}

Ada beberapa teori dalam Islam seperti dikutip Muhammad Ikhsan pada masa klasik, antara lain: al-Farabi mengatakan bahwa yang dapat dan boleh menjadi kepala negara adalah anggota masyarakat atau manusia yang paling sempurnah. Ibnu Abi rabi dalam karyanya Suluk al-Malik fi Tadbir al-Mamalik menekankan pada ketuhanan dan memadukannya dengan teori asal-usul negara. Imam al-Gazali dalam Iyha Ulumuddin melihat agama sebagai ordesosio-politik dan penguasa sebagai pemeliharanya. Ibnu khaldum dalam Muqaddimah juga mengatakan bahwa siyasah berdasarkan al-din adalah berguna dunia dan akhirat. ${ }^{11}$

Dalam konteks ini Bonar juga mendefinisikan negara sebagai suatu kesatuan hukum yang bersifat langgeng, yang di dalamnya mencakup institusi sosial yang melaksanakan kekuasaan hukum secara khusus dalam menangani masyarakat yang tinggal dalam wilayah tertentu, dan negara memiliki hak-hak kedaulatan, baik dengan kehendaknya sendiri maupun dengan

11 Muh. Ikhsan, Relasi Agama dan Negara: Studi Kritis Atas Pemikiran Politik Hizbut Tahrir ( Resume Disertasi Promosi Doktor) UIN Alauddin Makssar, 2014. h. 11. 
jalan penggunaan kekuatan fisik yang dimilikinya. ${ }^{12}$

Ibnnu Taimiyyah, Dr. Abd al-Karim Zaidan dan Fazlur Rahman sama-sama sepakat bahwa Islam memerlukan negara bagi pembumian ajaran-ajarannya.karena dengan adanya negara kita akan lebih efektif dan lebih terkontrol dalam melaksanakan amar ma'ruf nahi munkar dalam pelbagai aspek yang melingkupinya. Al-Qur'an sangat banyak menyinggung tentang mesin kekuasaan. Mesin kekuasaan yang dimaksud itu tak lain adalah negara, yang juga berfungsi sebagai alat pemaksa terhadap anggota masyarakat agar mematuhi undang-undang yang telah ditetapkan oleh lembaga yang berwenang untuk itu. ${ }^{13}$ Apakah mesin kekuasaan itu merupakan perpanjangan tangan dari agama atau semata-mata sebagai alat yang efektif untuk melaksanakan pesan-pesan moral agama. Amin Rais berpendapat bahwa Islam itu din dan daulah (agama dan negara $)^{14}$ pandangan yang sama juga dikemukakan Muhammad Yusuf Musa bahwa Islam itu din dan daulah. Beberapa pandangan di atas dipertegas oleh A Gaffar Aziz bahwa semua agama menurutnya yang datang sebelumnnya, Islam juga tidak bisa dilepaskan dari sebuah negara yang memberikan perlindungan dan pengikut setia yang menyebarkan ajarannya. Dari pandangan ini dapat dipahami bahwa semua

12 Yusuf Musa, Nidhamul Mulk fi alIslam, terjemah M. Thalib, Politik dan Negara dalam Islam ( jakarata:Al-Ikhlas, 1990), h. 24.

${ }^{13}$ Ahmad Syafi'i Ma'arif, Peta Bumi Intelektualisme Islam di Indonesia (Bandung: Mizan, 1995), h. 205

14 Amin Rais, Cakrawala Islam: Antara Cita dan Pakta ( Bandung:Mizan, 1997), h.56. agama mencakup urusan agama dan dunia secara integral. Tegasnya, Islam adalah agama dan negara, sebuah agama, sebuah agama yang menjadi sumber aturan hukum dan inspirasi. ${ }^{15}$

Beberapa pandangan terakhir di atas secara eksplisit menegaskan bahwa Islam sebagai sebuah agama juga mencakup doktrin dan sistem yang mengatur persoalan negara. Pandangan ini jelas sebagai bentuk upaya untuk menjadikan agama sebagai dasar yang paling fundamental dalam menjalankan mesin politik atau negara. Atau dengan bahasa lain upaya membumikan atau mengarah pada "politisasi agama". pandangan ini agak lebih normatif yang melihat teks-teks agama secara skripturalis.

Berbeda dengan Syafi'i Ma'arif yang tidak sepakat bahwa Islam adalah agama dan negara dengan alasan karena agama (din) adalah sesuatu yang immutable (tetap), sedangkan negara (daulah) adalah sesuatu yang mutable (berubah) sesuai tuntutan ruang dan waktu. Dengan kata lain, dengan menempatkan daulah setarap dengan posisi din berarti kita mengagungkan negara sebagaiman kita mengagungkan din. ${ }^{16}$ Meski Syafi'i Ma'arif memiliki guru yang sama dengan Amin Rais yang sama pernah berguru kepada Fazlur Rahman di Chicago University Amerika, bahkan memiliki organisasi yang sama yaitu Muhammadiyyah, namun memiliki pandangan yang berbeda soal hubungan agama dan negara. Amin Rais agak lebih

15 A.Gaffar Aziz, al-Din wala-Siyasah fi Adyan al-stalastah terjemah Ilyas Siraj, Berpolitik Untuk Agama:Missi Islam, Kristen, dan Yahudi Tentang Politik ( Yogyakarta: Pustaka Pelajar, 2000), h.49.

16 Ahmad Syafii Ma'arif, Op.Cit, h. 206 
fundamental, sementara Syafi'i Ma'arif agak sedikit sekuler.

Muin Salim juga secara panjang lebar menganalisis persoalan ini dalam Fiqhi Siyasah, Konsepsi Kekuasaan dalam alQur'an, menurutnya, al-Qur'an tidak menyatakan secara eksplisit bagaimana sistem politik terwujud. Tetapi ia menegaskan bahwa kekuasaan politik dijanjikan kepada orang-orang beriman dan beramal saleh. Ini berarti sistem politik terkait dengan kedua faktor tersebut.pada sisi lain keberadaan sebuah sistem politik terkait pula dengan ruang dan waktu. Ini berarti ia adalah budaya manusia sehingga keberadaannya tidak dapat dilepaskan dari dimensi kesejarahan. ${ }^{17}$

Karena itu lahirnya sistem politik Islami harus ditelusuri dari sebuah peristiwa sejarah.dalam hal ini peristiwa sejarah yang dimaksud adalah baiat atau mubayah keislaman, sebuah perikatan berisi pengakuan dan penaklukan diri kepada Islam sebagai agama. Konsekwensi dari baiat ini adalah terwujudnya sebuah masyarakat muslim yang dikendalikan oleh kekuasaan yang dipegang Rasulullah Saw. Dengan demikian terbentuklah sebuah sistem politik Islami yang pertama dengan fungsi-fungsi dan struktur yang sederhana dalam sebuah masyarakat negara kota. Perkembangan lebihlanjut dari sitem politik tersebut memilki supremasi atas kota madinah yang ditandai dengan lahirnya Piagam Madinah.dan dengan demikian,

${ }^{17}$ Muin Salim, Piqhi Siyasah, Konsepsi Kekuasaan Politik dalam al-Qur'an ( Jakarta: Pustaka Pelajar, 1994), h. 294. maka tegaklah sistem politik Islam dalam bentuk formal, sebuah negara. ${ }^{18}$

\section{Prinsip-Prinsip Kekuasaan dalam al- Qur'an: Inspirasi Islamisasi Politik}

Prinsip-prinsip politik dalam Islam dapat ditelusuri beberapa istilah kebahasaan yang disebutkan dalam al-Qur'an. Antara lain kata al-hukm, sulthan, al-mulk.

Kata al-hukm dan kata-kata yang terbentuk dari kata tersebut dipergunakan alQur'an sejumlah 210. ${ }^{19}$ Dalam bahasa Arab kata tersebut berpola masdar ${ }^{20}$ yang dapat dipergunakan dalam arti konotatif perbuatan atau sifat.berdasarkan hal ini, sebagai perbuatan, hukum bermakna membuat dan menjalankan keputusan, dan sebagai sifat, dalam hal ini obyek atau hasil perbuatan, kata tersebut merujuk kepada sesuatu yang diputuskan, yakni keputusan atau peraturan seperrti yang dikenal dalam bahasa Indonesia dengan kata hukum. ${ }^{21}$

Apabila makna tersebut dikaitkan dengan kehidupan masyarakat, maka kata tersebut mengandung makna pembuatan kebijaksanaan atau melaksanakannya sebagai upaya pengaturan masyarakat. Dari sini ditemukan hubungan kata hukm dengan konsep kekuasaan politik.

${ }^{18}$ Ibid., h. 295.

19 Diantaranya terdapat kata kerja dengan pola hakama" memutusklan perkara, membuat keputusan' 45 buah, pola ahkama"mengokohkan"dua kali, dan pola tahakama" berhakimkan atau mengikuti keputusan seseorang sekali. Kata al-hukm sendiri yang merupakan masdar kata kerja hakama yahkumu hukman dipergunakan 30 kali.lihat Muin Salim, Op.Cit. h. 159.

20 Dalam al-Qur'an ditemukan kata dalam bentuk masdar dankata kerja hakama yahkumu, lihat QS al-kalam, 68/2:36,39dan 48.

${ }^{21}$ Muin Salim, Op.Cit., h. 160. 
Selain dari kata hukm, ada juga kata sulthan, kata ini berakar dengan huruf-huruf sin, lam dan tha dengan makna pokok "kekuatan dan paksaan "bentuk yang ditemukan dalam al-Qur'an adalah kata kerja sallatha-yusallithu dan kata benda sulthan. Sedangkan kata kerja sallatha yang hanya dipergunakan dua kali mengandung makna "memberi kekuasaan atau kekuatan sehingga memperoleh kemenangan. ${ }^{22}$

Dari penggunnaan kata sulthan dapat diketahui bahwa kata tersebut berkonotasi sosiologis, karena ia berkaitan dengan kemampuan mengatasi orang lain. Selain kata sulthan juga ada kata al-mulk yang bermakna " keabsahan dan kemampuan " kata mulk yang berarti rajadan mulk yang berarti kekuasaan dapat ditemukan dalam alQur'an. ${ }^{23}$

Di samping penomena kebahasaan yang disebutkan dalam al-Qur'an di atas, prinsip-prinsip politik dalam Islam secara ekspilisit disebutkan dalam al-Qur'an tentang perintah memelihara amanah seperti dalam QS al-nisa:yang terjemahnya:

"sesungguhnya Allah memerintahkan kepada kamu agara kamu menunaikan amanat-amanat itu kepada pemiliknya dan memerintahkan kebijaksanaan diantara kamu supaya kamu menetapkannya dengan adil. Sesungguhnya Allah memberi pengajaran yang sebaik-baiknya kepada kamu. Sesungguhnya Allah maha mendengar lagi maha melihat. Hai orang-oarng yang beriman, taatilah Allah dan taatilah rasul-Nya

\footnotetext{
${ }^{22}$ Lihat QS. Al-Nisa, 4/92;90, lihat pula QS al-Hasyr, 59/101;6.

${ }^{23}$ Lihat QS al-Baqarah,2/ 87:241.
}

dan ulil amri dari kamu, maka jika kamu berselisih temtang sesuatu, maka kembalikanlah dia kepada Allah Rasul-Nya, jika kamu beriman kapada Allah dan hari kemudian. Itu adalah kebaikan dan penyelesaian yang sebaik-baiknya. ${ }^{24}$

Menurut Quraish Shihab ayat di atas dinilai oleh para ulama dan ahli tafsir sebagai prinsip-prinsip pokok yang menghimpun ajaran Islam tentang kekuasaan atau pemerintahan.bahkan Rasyid rida, berpendapat bahwa" seandainya tidak ada ayat lain yang berbicara tentang hal pemerintahan, maka ayat ini telah amat memadai."

Ibnu Jarir al-Thabari menyikapi ayat di atas bahwa ayat-ayat itu dialamatkan kepada para pemimpin umat agar mereka menuaikan hak-hak umat Islam seperti pembagian jarah dan penyelesaian perkara rakyat yang diserahkan kepada mereka utuk ditangani dengan baik dan adil. ${ }^{25}$

Amanat dimaksudkan berkaitan dengan banyak hal, salah satu diantaranya adalah perlakuan adil. Keadilan yang dituntut ini bukan hanya terhadap kelompok, golongan, atau kaum Muslimin saja, tetapi mencakup seluruh makhluk manusia bahkan seluruh makhluk. ${ }^{26}$ Amanat itu pada intinya adalah tugas mengelola bumi secara bertanggung jawab, dengan mempergunakan akal yang telah dianugerahkan Allah. ${ }^{27}$

24 Lihat Qsal-Nisa, 4/ 92,58-9.

25 Ibnu Jarir al-Thabari, Jamiul Bayan an Ta'wil Ayi al-Qur'an, ( T.np,t.th), h.145.

${ }^{26}$ Quraish Shihab, Wawasan Al-Qur'an: Tafsir Maudui Atas Pelbagai Persoalan Umat (Bandung: Mizan, 1998), h. 426.

27 M. Dawam Raharjo, Ensiklopedi alQur'an: Tafsir Sosial Berdasarkan Konsep- 
Ayat di atas juga disinggung tentang perintah menetapkan hukum dengan adil. Dalam konteks kata hukum yang telah disebutkan di atas, maka ungkapan hukum dalam ayat tersebut mencakup pengertian "membuat dan menetapkan hukum", perintah menegakkan hukum dengan adil mengandung arti agar penggunaan kekuasaan politik harus berdasarkan atau bertujuan memelihara martabat kemanusiaan.

Selain dari dua perintah di atas ayat tersebut juga menyebutkan perintah taat kepada Allah dan rasul, dan ulil amri. Tinjuan kronologis ayat tersebut mengandung ketaatan kepada Allah dan Rasulnya terlihat adanya pembentukan hukum. ${ }^{28}$ Namun demikian penggunaan kalimat setara dalam ayat tersebut memberi isyarat adanya kemandirian Rasulullah atau adanya kekuasaan yang dimilki Rasulullah membuat hukum. Kemandirian ini tidaklah bersifat mutlak, sebab perintah itu dikatakan dengan perintah ketaatan kepada Allah yang mendahuluinya. Adanya keterpautan antara kedua perintah ini memberi pengertian bahwa ketaatan kepada Rasulullah SAW tidak melampaui batas ketaatan kepada Allah.

Namun kata ulul amri yang juga disebutkan dalam ayat tersebut, menurut Qurais Shihab bahwa redaksi ayat di atas menggandengkan kata "taat kepada Allah dan Rasul, tetapi meniadakan kata itu pada ulil amri. Tidak disebutkannya kata taat pada ulil amri untuk memberi isyarat bahwa ketaatan kepada mereka tidak berdiri sendiri tetapi berkaitan atau bersyarat dengan ketaatan kepada Allah dan Rasul, dalam arti bila bertentangan dengan nilai-nilai ajaran Allah dan Rasul-Nya, maka tidak dibenarkan untuk taat kepada mereka. ${ }^{29}$

\section{E. Fenomema Sekularisasi Politik}

Ketika Eropa bangkit dengan munculnya Renaissance, seluruh masyarakat berhasil mendobrak kedok pemerintahan yang berkuasa. Sebagai dampak logis, para pemikir dan kaum negarawan Eropa berusaha menyingkirkan kaum gereja dari panggung politik, dan mendikotomikan permasalahan agama dari instrumen kenegaraan. Asumsi ini menjadi literatur umum yang mereka doktrinkan kebenak rakyaknya, dengan harapan akan menghilangkan trauma sejarah yang mereka alami sebelumnya. Ketika ekspansi dunia merambah khususnya ke negara-negara Islam, dogma kenegaraan mereka ini, juga ikut mewarnai teori-teori kenegaraan di negara jajahannya.

Dari sini muncul idiom dikotomi antara negara dan agama, sebagai doktrin legal kelompok sekuler Barat yang harus ditelan oleh seluruh penghuni dunia. Sampai di negara-negara yang mayoritas penduduknya Muslim sekalipun, dokrin ini dipaksakan untuk dapat diaplikasikan di dalam tatanan negara. Mereka menganalogikan sejarah perkembangan Islam sebagaimana agama Kristen di Eropa, dan menyamakannya dengan agama Kristen atau kelompok gerejanis yang menggunakan

Konsep Kunci ( Jakarta: Paramadina, 1096), h. 364.

\footnotetext{
${ }^{28}$ Muin Salim, Op.Cit., .
} 
dalih kesakralan agama untuk kepentingan kekuasaan. ${ }^{30}$

Dalam konteks ini Muhammad al Bahy mensinyalir upaya orientalis dan orang-orang Kristen untuk membelokkan pemahaman hubungan agama dan negara ketika mendekati Islam. Al-Bahy juga mencatat bahwa tidak sedikit kalangan modernis Muslim yang terpengaruh oleh orang-orang Barat dan seluruh pandangan hidupnya. ${ }^{31}$

Konsep negara di dalam Islam berbeda dengan konsep negara menurut Barat. Barat tidak melihat adanya titik temu antara negara dan agama. Keduanya berada dalam kutub yang berbeda, bahkan bertolak belakang. Dalam tatanan bernegara Barat sama sekali tidak memasukkan nilai-nilai normatif agama. Sebagian negara Barat memberikan kebebasan kepada warganya untuk memeluk agama, dan sebagian yang lain melarang, bahkan memeranginya dengan alasan agama adalah sumber kemunduran. ${ }^{32}$

Dari hasil penelitan yang banyak dilakukan oleh para sosiolog dan pengamat politik, proses sekularisasi ini kelihatannya merupakan trend yang semakin sulit dibendung.negara-negara yang muncul

${ }^{30}$ Hakim Taufik, Muhammad Imarah: Islam dan Urgensi Perubahan dalam Islam Garda Depan: Mosaik Pemikiran Islam Timur Tengah ( Bandung: Mizan, 2001), h. 212.

31 A. Gaffar Aziz, Op.Cit., h. 53.

32 Penderitaan ini bermula dari masa kekaisaran yang bersifat monarki, dengan kesucian gereja sebagai legitimasi kekuasaan. Oleh karenanya, pemerintahan dengan sistem ini sangat tertutupdari campur tangan rakyat. Mereka menggunakan dalih kekuasaan dan kesucian gerejanis untuk kepentingan kelompok elit. Hakim Taufik Loc.Cit. pasca Perang dunia II kelihatannya mengarah pada bentuk negara sekuler terutama dalam bidang ekonomi dan politik pendekatan teokratis dianggap tidak cocok lagi. ${ }^{33}$

Perlu dicatat bahwa masyarakat modern yang mendukung sekularisasi politik, tidak mesti dihakimi sebagai menolak dan anti agama, melainkan kurang percaya pada lembaga agama untuk menyelesaikan persoalan politik. Lebih dari itu, menurunnya kepercayaan kepada masyarakat modern terhadap lembaga agama adalah karena agama dinilai cenderung menutup kreativitas. Tentu saja pada level etis kesadaran beragama seseorang bisa saja akan mempengaruhi tindakan dan keputusan politiknya.

\section{F . Perdebatan hubungan Agama dan Negara \\ Seputar perdebatan agama dan} hubungannya dengan negara, ada beberapa pandangan yang bisa diangkat dalam tulisan ini. Ini merupakan indikasi yang cukup jelas betapa hangatnya perdebatan diskusi hubungan antara agarma dan negara. Dengan bahasa lain salah satu tema yang mewarnai diskursus pemikiran keislaman yang dapat dipetakan dalam dua arus pemikiran yaitu antara yang fundamental dan liberal.

Perdebatan dan diskusi mengenai hal ini sesungguhnya lebih terletak pada tataran konseptualisasi dan pola-pola hubungan antara keduanya. Perdebatan ini muncul dilatar belakangi oleh teks-teks agama sendiri yang pola hubungannya

${ }^{33}$ Komaruddin Hidayat, Op.Cit., h. 13. 
dikotomis. Agama dan negara seringkali dikesankan sebagai dua wilayah yang berhadapan. Misalnya sering dijumpai dengan ungkapan al-Islam huwa al-din wa al-daulah. ${ }^{34}$ Azyumardi Azra seperti dikutip Dede Rosyada juga melihat munculnya perdebatan ini diawali ketegangan perbedaan hubungan agama dan negara ini diilhami oleh hubungan yang agak kaku antara Islam sebagai agama dan negara. ${ }^{35}$

Konsep negara Islam pernah mewarnai polemik di Pakistan. Salah satu tokoh yang terlibat di dalamnya adalah Abu A'ala al-Maududi salah seorang tokoh fundamentalis Pakistan dan pendiri Jamaat Islami, mengusung konsep apa yang disebut teokrasi (theocracy) atau Maududi menyebut negara Islam yang dia sebut sebagai "kerajaan Tuhan." 36 Pola pikir al-Maududi yang fundamentalis terkristalkan dalam buku monumentalnya al-Hukumah alIslamiyah yang memuat konsepnya tentang negara Islam. Menurutnya, penguasa yang sebenarnya dalam pemerintahan adalah Allah Swt, yang berarti hanya Dialah satusatunya yang berhak membentuk undangundang. Umat Islam tidak berhak untuk membentuk hukum baru atau mengubah hukum Allah. Karena itu, perundangundangan yang berasal dari Allah merupakan asas negara Islam. Dalam tata

34 Ahmad Suaedy (ed), Pergulatan Pesantren Demokrasi ( Yogyakarata: LkiS, 2000), h.88.

35 Dede Rosyada, et.al, Pendidikan Kewargaan ( Civic Education) Demokrasi ,Hak Asasi Manusia dan Masyarakat Madani ( Jakarta: ICCE UIN Syarif Hidayatullah, 2000), h. 61 .

36 Taufik Adnan Amal, Islam dan Tantangan Modernitas: Studi Pemikiran Hukum Fazlur Rahman ( Bandung: Mizan, 1989), h. 60. negara Islam, menurut al-Maududi, tidak ada ketaatan kepada manusia kecuali sesuatu yang menjadi ketentuan Allah atau dalam rangka melaksanakan perintah-Nya. ${ }^{37}$

Hal yang dipahami dari pandangan di atas pemerintahan sebagai pengakuan terhadap kepemimpinan dan kekuasaan Tuhan di bidang perundang-undangan mutlak adanya. Yaitu menyerahkan segala kedaulatan hukum kepada pemimpinan dan kekuasaan Tuhan yang dilandasi sebuah kalimat bahwa manusia sebagai khalifah adalah mewakili Tuhan di bumi.

Pandangan al-Maududi ini masuk dalam kategori "otoritarianisme" dalam istilah Khaled $\mathrm{M}$ Abou El-Fadl, yaitu tindakan mengunci dan mengurung kehendak Tuhan atau kehendak teks, dalam sebuah penetapan makna, dan kemudian menyajikan penetapan tersebut sebagai sesuatu yang pasti, absolut, dan menentukan. ${ }^{38}$ Atau al-hakimiyyah dalam istilah Nasr Hamid Abu Zaid, yaitu mengklaim hak ketuhanan atas mereka karena ia mengklaim memiliki karakter ketuhanan yang paling agung. Setiap orang di antara mereka yang mengklaim tersebut, berarti ia menjadikan orang tersebut sebagai Tuhan selain Allah, dan mengakui ia

${ }^{37}$ M.Yusuf Wijaya, Visi-Visi Pemikiran Keislaman: Upaya Klastifikasi Pemikiran Keislaman Timur Tengah dalam Islam Garda Depan: Mosaik Pemikiran IslamTimur Tengah (Bandung: Mizan, 2001), h. 43.

38 Supriatatmoko, Konstruksi Otoritarianisme Khaled M Abou El- Fadl dalam Hermeneutika Al-Qur'an dan Hadis ( Yogyakarta: eLSAQ Press, 2010),h. 272. 
memiliki karakteristik ketuhanan yang paling agung. ${ }^{39}$

Pemikiran politik dalam hal kedaulatan Tuhan al-Maududi dibantai juga oleh Zapariyab Ahmad yang menurutnya memiliki kelemahan teramat mendasar. Sebab, menurut kalangan modernis, dengan membatasai kedaulatan Tuhan pada suatu negara Islam, maka konsekwensi yang langsung muncul darinya adalah bahwa Tuhan yang disebut-sebut oleh al-Qur'an bukanlah Tuhan yang eksklusif, tetapi Tuhan semesta alam danTuhan sekalian manusia. ${ }^{40}$ Ibnu Taimiyyah juga menyerang dan mengkritik al-Maududi karena melihat Islam sebagai suatu tata sosial yang mempunyai hukum tertinggi yakni hukum Tuhan. Itu sebabnya Ibnu Taimiyyah sama sekali tidak tertarik pada negara dan formasinya meski pun menerima negara itu sebagai suatu kebutuhan agama. ${ }^{41}$

Perdebatan hubungan agama dan negara juga pernah mewarnai blantika pemikiran Islam di Indonesia yang menurut Nurcholish Madjid munculnya kecenderungan yang bersifat apologis. Sikap apologis itu muncul dari dua jurusan, pertama, karena menguatnya apologi kepada idiologi Barat (modern) khususnya dalam bidang politik. Munculnya idologi-idiologi Barat sebagai invansi kultural menghancurkan harga diri umat Islam yang justru dirasakan terbelakang dalam bidangbidang tersebut. Rasa rendah diri inilah yang

39 Nashr Hamid Abu Zaid, Naq alKhithab al-Din ( al-Qahirah: Sina li al-Nasyr, 1994), h. 213.

40 Taufik Adnan Amal, Op.Cit., h.61.

41 Qamaruddin Khan, Teori Pemikiran Politik Ibnu Taimiyyah ( Bandung: Pustaka, 1995), h. 141. melahirkan apresisiasi idiogogis yang bersifat totaliter kepada Islam, sehingga melahirkan cita-cita " Negara Islam" kedua, legalisme,. Menurut Nurcholish Madjid, legalisme telah membawa sebagian kaum Muslim ke pikiran apologetis "Negara Islam". Legalis kapada Islam yang berbentuk penghayatan keislaman dengan gambaran bahwa Islam adalah struktur dan kumpulan hukum. ${ }^{42}$

Nurcholis sebagai eksponen pembaharu muda pemikiran Islam pada saat itu juga berpendapat mengenai "Negara Islam" bahwa: Dari tindakan yang lebih prinsipal, konsep "Negara Islam" itu adalah suatu distorsi hubungan proposional antara negara dan agama. Negara adalah salah satu segi kehidupan duniawi, yang dimensinya adalah rasional dan kolektif. Sedangkan agama adalah aspek kehidupan lain, yang dimensinya adalah spritual dan pribadi. Antara keduanya itu tetap harus dibedakan dalam cara pendekatannya. Karena suatu negara tak mungkin menempuh dimensi spritual, guna mengurus dan mengawasi motivasi atau sikap batin warga negaranya, maka tak mungkin pula memberikan predikat keagamaan pada negara. ${ }^{43}$ Pandangan Nurckolish di atas sebangun dengan pandangan Syafi'i Ma'arif yang sam-sama menganggap hubungan antara agama dan negara sebagai hubungan yang harus dipahami secara proposional. Agama adalah yang memiliki dimensi yang mengatur hal-hal yang bersifat spritual yang sifatnya tetap sementara negara memiliki

${ }^{42}$ Syafi'i Anwar, Op.Cit., h. 58.
Nurcholish $\quad$ Madjid, Kemoderenan dan Keindonesiaan ( Bandung: Mizan,1987), h. 256. 
dimensi yang mengatur hal-hal yang berdimensi sosia-kemanusiaan yang sifatnya berubah (dinamis). Sehingga keduanya harus memiliki ruang yang berbeda dalam hal penerapannya.

Nurcholish juga menyinggung soal partai Islam, liberalisasi dan sekularisme. Kebebasan berpikir, gagasan kemajuan,dan perlunya pemikiran baru yang liberal. Dalam soal partai Islam menurut Nurcholish bahwa partai-partai Islam sudah tidak menarik lagi. Dengan demikian Nurcholish melontarkan jargon yang agak provokatif, Islam Yes, Partai Islam, No. Penolakan terhadap institusi kepartaian politik Islam haruslah dipahami sebagai penolakan bukan karena Islamnya, tetapi penolakan terhadap pemamfaatan atas Islam oleh mereka yang terlibat dalam kehidupan partai politik Islam. ${ }^{44}$ Sebenarnya gagasan Nurcholish soal partai Islam juga merupakan kegelisahan Nurcholish dalam melihat fenomena politik di Indonesia pada saat itu yang dinilainya sebagian politisi mengeksplorasi agama sebagai alat yang paling ampuh dalam menjual "dagangan politiknya". Kelompok-kelompok politisi yang seperti inilah yang masuk dalam barisan "politisasi agama". Penolakan Nurcholish terhadap partai Islam sebenarnya juga tidak bisa dilepaskan dari pandangannya mengenai sekularisasi.

Namun perlu dipahami bahwa gagasan sekularisasi yang dimaksudkan Nurcholish, bukan sekularisme seperti yang dikenal di Barat. Tetapi sekularisai sebagai salah satu bentuk "liberalisasi"atau pembebasan terhadap pandangan-pandangan keliru yang sudah mapan. Lebih tegasnya

\footnotetext{
${ }^{44}$ Ibid., h. 205.
}

maksud dari sekularisasi yang diusung Nurcholish adalah sekularisasi yang diidealisasikannya tidak dimaksudkan sebagi penerapan sekularisme dan mengubah kaum Muslim menjadi sekuler. “ Tetapi dimaksudkan untuk menduniawikan nilainilai yang sudah semestinya bersifat duniawi, serta melepaskan umat Islam akan terbiasa dengan sikap mental untuk menguji kebeanaran suatu nilai di hadapan kenyataan material.

Gagasan-gagasan progresif Nurcholish itu kemudian dihujani kritik dari berbagai kalangan baik kalangan intelektual muda maupun para seniornya. Kalangan muda yang memberikan tanggapan antara lain Endang Saifuddin Anshary, Islamil Hasan Metarium, dan Abdul Qadir Djaelani. Sementara dari angkatan tua adalah Prof. M. Rasyidi, Mohammad Natsir, dan juga Hamka.

Gagasan sekularasasi yang dibangun Nurcholish, Endang tidak sependapat. Bagi Endang, Islam tidak mengenal sekularissai. sebab Islam bukanlah semata-mata sebuah agama, tetapi juga merupakan pandangan hidup yang lengkap. ${ }^{45}$ Kritikyang tidak langsung menyebut nama, namun jelas ditujukan kepada Nurcholish datang dari Amin Rais. Amin berpendapat bahwa anjuran melakukan sekularisasi, sekalipun dimaksudkan untuk memperbaharui pemahaman Islam, merupakan ajakan yang tidak mempunyai dasar dalam Islam. ${ }^{46}$ tanggapan keras juga datang dari Abdul Qadir Djaelani.Aktivis GPI ini mencurigai Nurcholis sedang berusaha mendorong umat Islam ke arah sekularisasi padahal Isalm

${ }^{45}$ Ibid., h. 60.

${ }^{46}$ Ibid., h. 73. 
sama sekali tidak mengenal pemisahan persoalan-persoaln dunia dan akhirat ${ }^{47}$ Gagasan sekularisasi Nurcholish wajar jika mendapatkan tantangan dari berbagai kalangan apalagi istilah ini sangat tabu dalam masyarakat Indonesia yang mayoritas yang memegang teguh terhadap prinsip agamanya masing-masing. Tapi perlu disikapi munculnya dilektika pemikiran tersebut diakibatkan dari cara berpikir dan pendekatan yang berbeda dalam memahami Islam. kelompok yang mengkritik Nurcholish bisa dikelompokkan sebagai salah satu eksponen pemikir liberal, sementara penentangnya sebagai kelompok fundamental.

Tentang konsep "Negara Islam," Endang juga mengkritik Nurcholish. Memang benar di dalam al-Qur'an tidak menyebut "negara Islam", tetapi mengingkari bahwa memberikan kaidahkaidah asasi tentang kenegaraan dan kemasyarakatan, adalah merupakan distorsi yang besar. Nurcholis menurut Endang berusaha membuktikan bahwa setiap umat Islam menuju kekuasaan politik tertinggi dalam negara sebagai tindakan menyaingi Tuhan, syirik, yang merupakan dosa besar tak terampuni. ${ }^{48}$

Sementara dari generasi tua datang dari Prof. Rasydi. Dia melontarkan kritikan tajam kepada Nurcholish dengan penggunaan kata sekularisasi yang dianggapya bukan bersumber dari tradisi, bahasa dan nilai-nilai otoritatif Islam. “ saudara Nurcholish menurut Prof. Rasyidi melukiskan seolah-olah Islam memerintahkan sekularisasi dalam arti

\footnotetext{
${ }^{47}$ Ibid., h. 61.

${ }^{48}$ Ibid.
}

tauhid. Kalau soalnya seperti yang dikemukanan oleh saudara Nurcholish, maka segala sesuatu telah menjadi arbitrer atau" semau gue". ${ }^{49}$ Sementara tentang soal "negara Islam" Rasyidi menilai pandangan Nurcholish sebagai sangat naif, yang bersumber dari kekacauan pikiran, tidak percaya keapada al-Qur'an, dan sepertinya hanya pernah membaca injil. Pandangan Nucholis yang melihat hubungan proposional antara agama dan negara juga dilihat oleh Rsyidi sebagai sikap orang yang tidak paham terhadap prinsip-prinsip kenegaraan dalam Islam. ${ }^{50}$

Selain Rasyidi dari angkatan tua, Muhammad Natsir dan Hamka. Natsir dalam suatu kesempatan ceramah di hadapan anggota-anggota HMI mengingatkan bahwa sekularisai hanya mengakibatkan kecintaan pada diri sendiri dan dunia secara berlebihan. Orang yang mementingkan sikap hidup sekularis, kata Natsir, akan berusaha mencari kepuasan duniawi dan meninggalkan segala bentuk nilai luhur. Sikap seperti ini menurut Natsir bertentangan dengan Islam. ${ }^{51}$ bila ingin memahami agama dan negara dalam Islam secra jernih, maka hendaknya mampu menghapuskan gambaran keliru tentang negara Islam. ${ }^{52}$ Demikian pula Hamka yang juga tidak menyebut nama dalam memberikan respon terhadap gagasan pembaharuan Nurcholish. Hamka perpendapat bahwa suatu gerakan tajdid tidak peerlu perombak atau memperbaharui

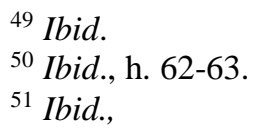
Pilar-Pilar Demokrasi (Yogyakarta: Gama Media, 1999), h. 83. 
seluruh bangunan Islam agar dapat memenuhi tuntutan dan kebutuhan manusia modern. ${ }^{53}$ Hamka juga secara tegas menolak teori pemisahan agama dan negara. Dengan menyebut nama Islam saja, kita teringat kepada suatu agama, yang mengatur hidup dunia dan akhirat, diri dan masyarakat bersama. ${ }^{54}$ Walau Nastsir dan Hamka tidak langsung menyebut nama sudah bisa diduga bahwa kritikannya itu dialamatkan kepada Nurcholish apalagi kritikan itu muncul pada saat ramai-ramainya Nurcholis mendeklerasikan ide-ide sekularisasi yang substansinya adalah pemisahan agama dan negara. Kemudian pemahamannya tentang "negara Islam" yang menurutnya tidak juga selaras dengan bangsa Indonesia yang masyarakatnya heterogen. Sangat tidak realistis yang dinilainya Indonesia jika mau dijadikan sebuah negara yang diatur oleh aturan agama. Di samping itu Nurcholis sangat menentang penomena politisasi agama yang memperalat agama demi kepentingan politik.

\section{H. PENUTUP}

Dalam al-Qur'an memang ada prinsip-prinsip kekuasaan. Dari sudut kebahasaan, al-Qur'an menggunakan istilah al-hukm, sultan, dan al-mulk. Di samping itu juga ada istilah amanat, taat kepada Allah dan rasul-Nya. Istilah-istilah ini kemudian dijadikan dasar bagi sebagian kelompok dalam memahami adanya konsep politik dalam Islam. al-Qur'an juga dalam surah almaidah ayat 44 . Tentang dianggap kafir bagi

${ }^{53}$ Syafi'i Anwar, Op.Cit., h.64.

54 Ahmad M. Sewang, Hubungan Agama dan Negara: Studi Pemikiran Politik Buya Hamka (Makassar: Pss UIN Alauddin Makassar,2003), h. 55. orang yang tidak mau menjadikan hukum yang ditirunkan Allah. Ayat ini sering dipahami secara tekstual oleh kalangan fundamental yang sangat bernafsu mendirikan "negara Islam".

Dalam wacana pemikiran Islam terdapat dua pola pemikiran politik dalam kaitan hubungan antara agama dan negara. Pertama paradigma pemikiran Islamisasi pengetahuan yang melihat adanya hubungan agama dan negara baik secara substantif maupun secara simbiosis-mutulisme yang saling menguntungkan. Kedua, paradigma pemikiran sekularistik. Paradigma ini menolak agama dicampur adukkan dengan persoalan negara. Agama adalah persoalan akhirat sementara negara adalah persoalan dunia. Agama adalah tidak berubah sementara urusan negara selalu berubah.

\section{DAFTAR} PUSTAKA

A M. Sewang, Ahmad Hubungan Agama dan Negara: Studi Pemikiran Politik Buya Hamka . Makassar: Pss UIN Alauddin Makassar, 2003.

A.Aziz, Gaffar. al-Din wala-Siyasah $f i$ Adyan al-stalastah terjemah Ilyas Siraj dengan judul Berpolitik Untuk Agama:Missi Islam,Kristen, dan Yahudi Tentang Politik. Yogyakarta: Pustaka Pelajar, 2000.

Abu Zaid, Nashr Hamid. Naq al-Khitahab al-din. al-Qahirah: Sina li alNasyr, 1994.

Adnan Amal, Taufik Islam dan Tantangan Modernitas: Studi Pemikiran 
Hukum Fazlur Rahman. Bandung: Mizan, 1989.

al-Thabari, Ibnu Jarir. Jamiul Bayan an Ta'wil ayi al-Qur'an, T.np,t.th.

Anshari, Rahman Thohir. Islam dalam Wacana Pemikiran Moderat: Analisis terhadap Pemnikiran Muhammad Quthb dalam Islam Garda Depan: Mosaik Pemikiran Islam Timur Tengah. Bandung: Mizan, 2001.

Anwar, M. Syafi'i, Pemikiran dan Aksi Islam Indonesia: Sebuah Kajian Politik Tentang Cendikiawan Muslim Orde baru. jakarta: Paramadina, 19195.

Hidayat, Komaruddin. Tragedi Raja Midas: Moralitas Agama dan Krisis Modernisme. Jakarata: Paramadina, 1998.

Ikhsan, Muh. Relasi Agama dan Negara: Studi Kritis Atas Pemikiran Politik Hizbut Tahrir. (resume Diseetasi promosi Doktor) UIN Alauddin Makssar, 2014.

Khan, Qamaruddin. Teori Pemikiran Politik Ibnu Taimiyyah. Bandung: Pustaka, 1995.

M.Echols John dan Hasan Sadily. kamus Inggris Indonesia. Jakarta: Gramedia, 1981.

Madjid, Nurcholish. Islam, Kemoderenan dan Keindonesiaan. Bandung: Mizan,1987.

Mahfud MD, Moh. Hukum dan Pilar-Pilar Demokrasi. Yogyakarta: Gama Media, 1999.

Musa, Yusuf. Nidhamul mulk fi al-Islam, yang diterjemahkan M. Thalib,
Politik dan Negara dalam Islam. jakarata:Al-Ikhlas, 1990.

Raharjo, M. Dawam. Ensiklopedi al-Qur'an: Tafsir Sosial Berdasarkan Konsep-Konsep Kunci. Jakarta: Paramadina, 1096.

Rais, Amin Cakrawala Islam: Antara Cita dan Pakta. Bandung:Mizan, 1997.

Rosyada, Dede. et.al, Pendidikan Kewargaan ( Civic Education) Demokrasi, Hak Asasi Manusia dan Masyarakat Madani. Jakarta: ICCE UIN Syarif Hidayatullah, 2000.

Salim, Muin. Piqhi Siyasah, Konsepsi Kekuasaan politik dalam alQur'an. Jakarta: Pustaka Pelajar, 1994.

Shihab, Quraish. wawasan Al-Qur'an:

Tafsir Maudui Atas Pelbagai Persoalan Umat. Bandung: Mizan, 1998.

Suaedy, Ahmad (ed), Pergulatan Pesantren Demokrasi.Yogyakarata: LkiS, 2000.

Supriatatmoko, Konstruksi Otoritarianisme Khaled M Abou El- Fadl dalam Hermeneutika Al-Qur'an dan Hadis. Yogyakarta: eLSAQ Press, 2010.

Syafi'i ma'arif, Ahmad. Peta Bumi Intelektualisme Islam di Indonesia. Bandung: Mizan, 1995.

Taufik, Hakim, Muhammad Imarah: Islam dan Urgensi Perubahan dalam Islam Garda Depan: Mosaik Pemikiran Islam Timur Tengah. Bandung: Mizan, 2001.

Team Pustaka Phoenix, Kamus Besar Bahasa Indonesia edisi baru. 
Jakarta: Kepustakaan nasional, 2007.

W.J.Spurdawarminta, Kamus Umum Bahasa Indonesia. Jakarta: Balai Pustaka, 1983

Warson al-Munawwir, Ahmad. Kamus AlMunawwir Arab-Indonesia Terlengkap. Yogyakarta: Pondok Pesantren al-Munawwir, 1984.

Wijaya, M. Yusuf. Visi-Visi Pemikiran Keislaman: Upaya Klastifikasi Pemikiran Keislaman Timur Tengah dalam Islam Garda Depan: Mosaik Pemikiran IslamTimur Tengah. Bandung: Mizan, 2001. 